\title{
PENGARUH MODEL PEMBELAJARAN SNOWBALL THROWING BERBASIS PENILAIAN PROYEK TERHADAP HASIL BELAJAR IPS
}

\author{
Ni Putu Efiyanti ${ }^{1}$, Ni Ketut Suarni ${ }^{2}$, Desak Putu Parmiti ${ }^{3}$ \\ ${ }^{13}$ Jurusan PGSD, ${ }^{2}$ Jurusan BK, Universitas Pendidikan Ganesha \\ Singaraja, Indonesia \\ e-mail: putu.efiyanti@gmail.com ${ }^{1}$, ni.ketut suarni@undiksha.ac.id², \\ dskpt_parmiti@yahoo.co.id ${ }^{3}$
}

\begin{abstract}
Abstrak
Penelitian ini bertujuan untuk mengetahui pengaruh yang signifikan model pembelajaran Snowball Throwing berbasis penilaian proyek terhadap hasil belajar IPS siswa kelas IV SD di Gugus IV Kecamatan Banjar Kabupaten Buleleng Tahun Pelajaran 2017/2018. Penelitian ini adalah eksperimen semu (Quasi Eksperimen), dengan desain Non equivalent post-test only control group design. Populasi penelitian ini adalah seluruh kelas IV SDN 1 Banjar dan kelas IV SDN 5 Banjar. Sampel ditentukan menggunakan teknik random sampling. Data hasil belajar dikumpulkan menggunakan tes pilihan ganda. Data yang diperoleh dianalisis menggunakan polled varians. Hasil penelitian menunjukkan bahwa terdapat pengaruh yang signifikan model pembelajaran Snowball Throwing berbasis penilaian proyek terhadap hasil belajar IPS siswa kelas IV SD di Gugus IV Kecamatan Banjar Kabupaten Buleleng. Hal ini ditunjukan oleh $t_{\text {hitung }}(8,179)>t_{\text {tab }}(2,021)$. Selanjutnya, rata-rata (mean) kelompok eksperimen $(22,5)$ lebih besar daripada rata-rata (mean) kelompok kontrol $(14,6)$. Dengan demikian, model pembelajaran Snowball Throwing berbasis penilaian proyek berpengaruh terhadap hasil belajar IPS siswa kelas IV SD tahun pelajaran 2017/2018 di Gugus IV Kecamatan Banjar Kabupaten Buleleng. Hal tersebut menandakan adanya perbedaan hasil belajar IPS antara kelompok eksperimen dengan kelompok kontrol yang ditandai dengan lebih tingginya mean kelompok eksperimen daripada kelompok kontrol.
\end{abstract}

Kata kunci: Snowball Throwing, Penilaian Proyek, Hasil Belajar IPS

\begin{abstract}
This study aimed to determine the significant effect of the learning model of Snowball Throwing based on project assessment toward IPS students' result study of fourth graders of an elementary school in Gugus IV Banjar Sub-district, Buleleng Regency, Academic Year 2017/2018. This research was a quasi-experimental (Quasi Eksperimen), with a non-equivalent design post-test only control group design. The population of this research was all grades IV in SDN 1 Banjar and students in grade IV in SDN 5 Banjar. The sample was determined by using a random sampling technique. Learning result data was collected by using multiple-choice tests. The data obtained were analyzed by using polled variance. The results showed that there was a significant effect of the learning model of Snowball Throwing based on project assessment toward IPS students' result study of fourth-grade elementary school in Gugus IV Banjar Buleleng Regency. This is indicated by thitung $(8,179)>$ ttab (2.021). Furthermore, the mean score (mean) of the experimental group (22.5) was higher than the control group's mean (mean) (14.6) score. Thus, the learning model of Snowball Throwing based on project assessment affects the resulting study of IPS in fourth-grade students of the elementary school year 2017/2018 in Gugus IV Banjar Sub-district, Buleleng District. This indicates a difference in IPS students' result study between the experimental group and the control group, which was marked by a higher mean of the experimental group than the control group.
\end{abstract}

Keywords: Snowball Throwing, Project Assessment, IPS Learning Result 


\section{Pendahuluan}

Pada era Globalisasi ini pendidikan sangat diutamakan oleh pemerintah. Bagi setiap manusia pendidikan tidak seperti pada zaman dahulu yang memilih untuk tidak melanjutkan pendidikan kemudian memilih untuk bekerja. Sekolah sebagai lembaga pendidikan membantu mengembangkan potensi yang dimiliki peserta didik melalui proses pembelajaran. Menurut Shoimin (2014:20) pendidikan merupakan "hal yang penting dalam membangun peradaban bangsa. Pendidikan adalah satu-satunya asset untuk membangun sumber daya manusia yang berkualitas". Menurut Djahir (2014) Mutu pendidikan dapat terwujud dengan jalan sistem pendidikan nasional harus mampu menjamin pemerataan kesempatan pendidikan, peningkatan kualitas pendidikan, serta relevansi dan efisiensi manajemen pendidikan untuk menghadapi tantangan sesuai dengan tuntutan perubahan kehidupan lokal, nasional, global sehingga diperlukan pembaharuan pendidikan secara terencana, terarah, dan berkesinambungan.

Perkembangan IPTEK sekarang ini semakin bertambah maju dan modern. Sebagai seorang guru, kita dapat memanfaatkan perkembangan tersebut dalam pembelajaran. Namun, tidak semua guru memanfaatkan itu karena ada guru yang masih menggunakan strategi dan metode pembelajaran yang mengacu pada zaman dahulu. Akibatnya, guru menjadi malas untuk melakukan inovasi. Padahal, dalam pembelajaran, inovasi sangat diperlukan. Pembelajaran yang dilakukan dalam proses pembelajaran diharapkan adanya interaksi yang menciptakan pembelajaran yang kondusif. Proses pembelajaran yang dapat memotivasi siswa untuk tidak pasif dalam pembelajaran.

Suwatra,dkk (2015:3) menyatakan istilah pembelajaran merupakan "istilah yang digunakan untuk menunjukkan kegiatan guru dan siswa". Salah satu mata pelajaran yang dibelajarkan di Sekolah Dasar adalah IPS. Hidayati,dkk (2010:1.11) menyatakan bahwa bahwa mempelajari IPS pada hakekatnya adalah "menelaah interaksi antara individu dan masyarakat dengan lingkungan (fisik dan social-budaya)". Materi IPS digali dari segala aspek kehidupan praktis sehari-hari di masyarakat. Oleh karena itu, pengajaran IPS yang merupakan masyarakat sebagai sumber dan objeknya merupakan suatau bidang ilmu yang berpijak pada kenyataan.

Namun kenyatannya, di Sekolah Dasar termasuk di Gugus IV Kecamatan Banjar pembelajaran masih belum sesuai harapan guru. Salah satu kendala yang dirasakan oleh guru kelas yaitu perhatian siswa yang kurang fokus terhadap materi pelajaran. Hal tersebut diperkuat oleh hasil wawancara dan observasi pembelajaran IPS di kelas IV SD yang ada di Gugus IV Kecamatan Banjar.

Berdasarkan data yang diperoleh, dapat dilihat masih rendahnya rata-rata nilai hasil belajar IPS yang masih di bawah KKM. Observasi awal yang dilakukan di SD yang ada di Gugus IV Kecamatan Banjar dengan guru mata pelajaran IPS di kelas IV dilakukan secara lebih mendalam, terungkap bahwa hasil belajar siswa pada mata pelajaran IPS tergolong cukup rendah.

Rendahnya hasil belajar pada mata pelajaran IPS disebabkan oleh dua faktor yaitu oleh guru dan siswa itu sendiri. Penyebab rendahnya ketercapaian hasil belajar siswa dalam mata pelajaran IPS disebabkan oleh faktor guru diantaranya (a) dalam proses pembelajaran guru menggunakan model pembelajaran konvensional yaitu ceramah, guru jarang menggunakan model pembelajaran yang kooperatif, (b) Guru hanya menjelaskan materi pelajaran dengan menginstrusikan siswa untuk membaca. Kemudian kendala guru dalam proses pembelajaran yaitu (1) kurangnya perhatian siswa pada saat guru menjelaskan materi pelajaran, (2) hanya ada beberapa siswa, (3) pada saat diajak untuk melakukan experiment hanya beberapa saja yang mengikuti instruksi guru dengan baik. (4) interaksi siswa kurang pada saat pembelajaran khususnya saat menyelesaikan tugas yang diberikan guru sehingga tugas tidak dapat diselesaikan tepat waktu.

Hasil wawancara yang dilakukan dengan siswa, mata pelajaran IPS merupakan mata pelajaran yang kurang disukai karena membosankan dan sulit untuk dimengerti. Masalah tersebut menyebabkan siswa kesulitan memahami konsep-konsep pada pelajaran IPS. 
Guru kurang mendorong siswa untuk belajar secara kondusif, sehingga penyajian materi pelajaran oleh guru cenderung monoton.

Proses belajar siswa sangat dipengaruhi oleh sikap, emosi, motivasi, penyesuaian diri dan sebagainya . Apabila siswa merasa terpaksa dalam mengikuti suatu pelajaran, mereka akan kesulitan untuk menerima pelajaran atau materi-materi yang diberikan oleh guru. Salah satu tugas pendidik atau guru adalah menciptakan suasana pembelajaran yang dapat memotivasi siswa untuk senantiasa belajar dengan baik dan bersemangat. Oleh karena itu, guru hendaknya dapat memilih metode yang akan diterapkan, media pembelajaran yang akan digunakan dan model pembelajaran yang sesuai dengan materi pelajaran. Berdasarkan hasil wawancara, terlihat hubungan antara proses pembelajaran dengan kendala yang dihadapi oleh guru, yaitu (1) menerapkan model pembelajaran konvensional secara terus-menerus dapat meyebabkan siswa merasa bosan dan jenuh dalam mengikuti pembelajaran, rendahnya motivasi belajar pada siswa menyebabkan rendahnya hasil belajar siswa khususnya pada mata pelajaran IPS. (2) sulitnya menarik perhatian siswa dalam pembelajaran sehingga siswa sulit memahami materi pelajaran dengan baik. (3) interaksi antara siswa dengan siswa sulit ditumbuhkan sehingga komunikasi yang baik belum tercipta dalam tim atau kelompok pada saat menyelesaikan tugas yang diberikan. Maka dari itu, guru harus dapat menciptakan suasana yang kondusif dan membuat pembelajaran menjadi efektif dan menyenangkan. Shoimin (2014:18) menyatakan "agar pembelajaran menyenangkan, perlu adanya perubahan cara mengajar dari model pembelajaran tradisional menuju model pembelajaran yang inovatif". Model pembelajaran yang diterapkan disesuaikan dengan materi yang akan dipelajari oleh siswa. Salah satunya model pembelajaran yang membuat siswa akan lebih memperhatikan penjelasan guru selain guru yang menjelaskan materi, siswa juga terlibat dalam menjelaskan materi kepada siswa yang lainnya. Model pembelajaran Snowball Throwing merupakan model pembelajaran yang dapat menciptakan suasana belajar yang menyenangkan, siswa akan menjadi lebih aktif dan terlibat langsung dalam proses pembelajaran. Menurut Dewi (2013) model pembelajaran Snowball Throwing, "dalam proses pembelajarannya siswa diberikan kesempatan untuk aktif dalam kegiatan pembelajaran melalui diskusi".

Salah satu model pembelajaran yang sesuai untuk menyelesaikan masalah tersebut adalah model pembelajaran Snowball Throwing atau disebut dengan melempar bola salju. Menurut Sunistini (2013) Pembelajaran dengan model Snowball Throwing merupakan salah satu modifikasi dari teknik bertanya yang menitikberatkan pada kemampuan merumuskan pertanyaan yang dikemas dalam sebuah permainan yang menarik yaitu saling melemparkan bola salju (Snowball Throwing) yang berisi pertanyaan kepada sesama teman. Model yang dikemas dalam sebuah permainan ini membutuhkan kemampuan yang sangat sederhana yang bisa dilakukan oleh hampir semua siswa dalam mengemukakan pertanyaan sesuai dengan materi yang dipelajarinya. Menurut Yuliati (2015) Model pembelajaran kooperatatif Snowball Throwing merupakan salah satu dari sekian banyak tipe pembelajaran kooperatif. Model pembelajaran kooperatif tipe Snowball Thowring ini selalu diawali dengan membagi kelas menjadi beberapa kelompok, dimana setiap kolompok memiliki satu orang ketua yang akan mewakili teman sekelompoknya untuk mendengarkan penjelasan dari guru tentang materi yang akan di pelaJari. Setiap siswadi berikan kesempatan untuk menuliskan pertanyaan di selembar kertas mengenai hal-hal yang kurang atau belum mereka pahami guna membentuk pola pikir yang mandiri bagi setiap siswa. Menurut Rosidah (2017) Model pembelajaran kooperatif tipe Snowball Throwing dapat menigkatkan aktivitas dan kreatifitas siswa, melatih siswa belajar mandiri dalam pengetahuan berdasarkan diskusi, mengembangkan kemampuan berpikir siswa dalam mendiskusikan dan meyelesaikan tugas belajar, mengembangkan kemampuan mengemukakan pendapat, meningkatkan kemampuan menjelaskan kembali materi yang diperoleh berdasarkan diskusi, dan meningkatkan hasil belajar siswa. Model pembelajaran Snowball Throwing merupakan pengembangan dari model pembelajaran diskusi dan merupakan bagian dari model pembelajaran kooperatif. Hanya saja, pada model ini kegiatan belajar diatur sedemikian rupa sehingga proses belajar mengajar dapat berlangsung dengan lebih menyenangkan. Menurut 
Shoimin (2014:174) "salah satu permasalahan serius yang sering terjadi dalam proses belajar adalah adanya perasaan ragu pada diri siswa untuk menyampaikan permasalahan yang dialaminya dalam memahami materi pelajaran". Berkaitan dengan hal tersebut, melalui menerapkan model pembelajaran Snowball Throwing siswa akan lebih terlatih untuk mempersiapkan diri.

Namun dalam perkembangan pendidikan sekarang ini, penggunaan satu model dalam pembelajaran belum tentu bisa menjamin tercapainya hasil yang maksimal. Karena, kemampuan dan karakteristik siswa yang bervariasi sehingga siswa. Oleh karena itu, dibutuhkan penggabungan bantuan untuk mengoptimalkan model pembelajaran yang digunakan dalam pembelajaran, salah satunya Penilaian Proyek yaitu tugas yang diberikan oleh guru harus diselesaikan dalam waktu atau periode yang ditentukan. Di kelas, guru mungkin menekankan penilaian proyek pada prosesnya dan menggunakannya sebagai sarana untuk mengembangkan dan memonitor keterampilan siswa dalam merencanakan, menyelidiki, dan menganalisis proyek. Majid (2012:207) menyatakan "guru juga dapat menggunakan produk suatu proyek untuk menilai kemampuan siswa dalam mengkomunikasikan temuan-temuan dengan bentuk yang tepat dan dalam hal mempresentasikan hasil melalui display visual dan laporan akhir".

Berdasarkan pemikiran tersebut, maka perlu dilakukan penelitian yang berjudul "Pengaruh Model Pembelajaran Snowball Throwing Berbasis Penilaian Proyek Terhadap Hasil Belajar IPS Siswa Kelas IV SD di Gugus IV Kecamatan Banjar Kabupaten Buleleng Tahun Pelajaran 2017/2018".

\section{Metode}

Penelitian ini dilaksanakan di SD Gugus IV Kecamatan Banjar, Kabupaten Buleleng. Sedangkan waktu penelitian direncankaan pada semester genap tahu $n$ pelajaran 2017/2018. Penelitian ini mengikuti desain penelitian eksperimen semu (quasi eksperimen). Rancangan penelitian yang digunakan adalah Post-test Only Control Group Design, seperti Tabel 1.

Tabel 1. Desain Penelitian

\begin{tabular}{cccc}
\hline Kelompok & Perlakuan & Tes akhir \\
\hline $\mathrm{E}$ & $\mathrm{X}$ & $\mathrm{O}_{1}$ \\
$\mathrm{~K}$ & - & $\mathrm{O}_{2}$ \\
\hline
\end{tabular}

Keterangan:

$\mathrm{E}=$ Kelompok Eksperimen

$\mathrm{K}=$ Kelompok Kontrol

$\mathrm{X}=$ Perlakuan treatmen yang diberikan kepada kelompok eksperimen dengan model pembelajaran Snowball Throwing Berbasis Penilaian Proyek.

- $\quad$ = Tidak mendapat perlakuan atau kelompok kontrol belajar seperti biasanya secara konvensional

$\mathrm{O}_{1} \quad=$ Post-test untuk kelompok eksperimen

$\mathrm{O}_{2}=$ Post-test untuk kelompok control

Populasi memiliki peranan yang sangat penting. Populasi adalah sejumlah individu yang dijadikan sebagai subjek/objek penelitian yang memiliki kriteria tertentu. Sesuai dengan tujuan dari penelitian ini, maka yang dijadikan populasi dalam penelitian ini adalah siswa kelas IV di Gugus IV Kecamatan Banjar Kabupaten Buleleng yang menggunakan KTSP. Adapun sebaran siswa kelas IV di Gugus IV Kecamatan Banjar Kabupaten Buleleng.

Untuk mengetahui setara atau tidaknya kemampuan siswa kelas IV masing-masing SD, terlebih dahulu dilakukan uji kesetaraan. Uji kesetaraan ini dilakukan dengan menganalisis nilai hasil belajar IPS, analisis yang digunakan dalam uji kesetaraan yaitu 
analisis varians satu jalur (Anava A). Berdasarkan hasil analisis Anava Satu Jalur pada taraf signifikansi $5 \%$ diperoleh nilai $F_{\text {hitung }}$ sebesar 2,58 sedangkan nilai $F_{\text {tabel }}$ pada $\mathrm{db}_{\text {antar }}=3$ dan $\mathrm{db}_{\text {dalam }}=80$ adalah 2,72. Dengan demikian terlihat bahwa nilai $F_{\text {hitung }}<F_{\text {tabel }}(2,58<2,72)$, sehingga $\mathrm{H}_{0}$ diterima dan $\mathrm{H}_{1}$ ditolak. Jadi, tidak terdapat perbedaan hasil UAS semester ganjil tahun pelajaran 2017/2018 mata pelajaran IPS pada siswa kelas IV SD di Gugus IV Kecamatan Banjar Kabupaten Buleleng. Dengan kata lain, bahwa kemampuan siswa kelas IV SD di Gugus IV Kecamatan Banjar Kabupaten Buleleng yang menggunakan KTSP adalah setara.

Sampel adalah bagian dari jumlah dan karakteristik populasi yang mewakili seluruh populasi menggunakan teknik tertentu. Sebelum dilakukannya pemilihan sampel, terlebih dahulu dilakukan uji kesetaraan untuk mengetahui kemampuan siswa kelas IV masingmasing SD sudah setara atau belum. Setelah memperoleh hasil perhitungan uji kesetaraan, maka langkah selanjutnya pemilihan sampel yang digunakan untuk menentukan kelompok eksperimen dan kelompok kontrol adalah teknik random sampling dengan cara undian. Teknik pengambilan sampel yang digunakan dalam penelitian ini adalah teknik random sampling dengan cara undian. Teknik random sampling dikatakan sederhana. Menurut Sugiyono (2016:120) "karena pengambilan anggota sampel dari populasi dilakukan secara acak tanpa memperhatikan strata yang ada dalam populasi itu". Menurut Winarno (dalam Agung, 2014) alasan pengambilan sampel dengan cara undian karena cara ini cukup sederhana dan memungkinkan ketidakadilan dapat dihindari. Data yang telah dikumpulkan dianalisis dengan menggunakan statistik deskriptif dan statistik inferensial. Statistik deskriptif berfungsi untuk mengelompokkan data, memaparkan serta menyajikan hasil olahan. Statistik deskriptif yang digunakan dalam penelitian ini yaitu mean (rata-rata), standar deviasi dan varians. Sedangkan statistik inferensial berfungsi untuk menggeneralisasikan hasil penelitian yang dilakukan pada sampel bagi populasi. Statistik inferensial digunakan untuk menguji hipotesis melalui uji-t (polled varians) yang diawali dengan analisis prasyarat yaitu uji normalitas sebaran data dan uji homogenitas.

\section{Hasil dan Pembahasan}

Deskripsi data hasil penelitian meliputi (1) deskripsi data hasil post-test kelompok siswa yang mengikuti model pembelajaran Snowball Throwing berbasis penilaian proyek (eksperimen) dan deskripsi data hasil post-test kelompok siswa yang mengikuti pembelajaran konvensional (kontrol). Rekapitulasi hasil perhitungan data hasil post-test disajikan pada Tabel 2. Rekapitulasi Hasil Perhitungan Skor Hasil Belajar IPS Kelompok Eksperimen dan Kelompok Kontrol.

Tabel 2. Rekapitulasi Hasil Perhitungan Skor Hasil Belajar IPS

\begin{tabular}{ccc}
\hline Hasil Analisis & $\begin{array}{c}\text { Kelompok } \\
\text { Eksperimen }\end{array}$ & Kelompok kontrol \\
\hline Mean & 22,5 & 14,6 \\
Median & 23,5 & 14,5 \\
Modus & 23,7 & 13,1 \\
Varians & 9,986 & 9,324 \\
Standar Deviasi & 3,128 & 3,053 \\
Skor Minimum & 17 & 8 \\
Skor Maksimum & 27 & 19 \\
\hline
\end{tabular}

Berdasarkan Tabel di atas, dapat dideskripsikan modus (Mo), median (Md), mean (M), standar deviasi $(\mathrm{s})$, dan varians $\left(\mathrm{s}^{2}\right)$ dari data hasil belajar IPS kelompok eksperimen, yaitu modus $(\mathrm{Mo})=23,7$, median $(\mathrm{Md})=23,5$, mean $(\mathrm{M})=22,5$, standar deviasi $(\mathrm{s})=3,128$, dan varians $\left(s^{2}\right)=9,986$. tinggi. Adapun histogram disajikan pada Gambar 1. berikut. 


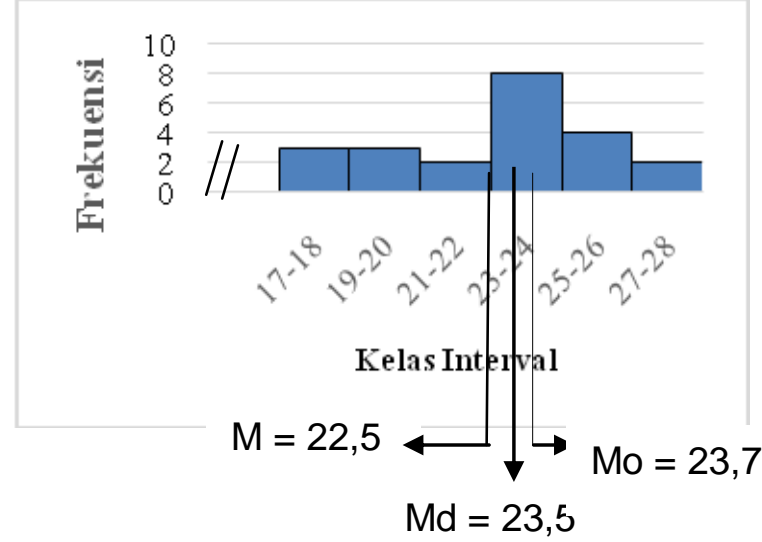

\section{Gambar 1. Histogram Data Hasil Belajar IPS Kelas Eksperimen}

Berdasarkan Gambar 1. terlihat kelompok siswa yang dibelajarkan dengan menggunakan model pembelajaran Snowball Throwing Berbasis Penilaian Proyek menunjukkan $\mathrm{Mo}>\mathrm{Md}>\mathrm{M}(23,7>23,5>22,5)$. Hal ini menunjukkan bahwa sebagian besar skor cenderung tinggi. Jika dikonversi ke dalam Penelitian Acuan Ideal Teoretik Skala Lima Berada pada kategori baik. Sedangkan kelompok kontrol dapat dideskripsikan modus (mo), median (Md), mean (M), standar deviasi (s), dan varians $\left(\mathrm{s}^{2}\right)$ dari data hasil belajar IPS kelompok kontrol, yaitu modus $(\mathrm{Mo})=13,1$, median $(\mathrm{Md})=14,5$, mean $(\mathrm{M})=14,6$, standar deviasi $(s)=3,053$, dan varians $\left(s^{2}\right)=9,234$. Apabila digambarkan ke dalam bentuk histogram akan tampak seperti Gambar 2. berikut.

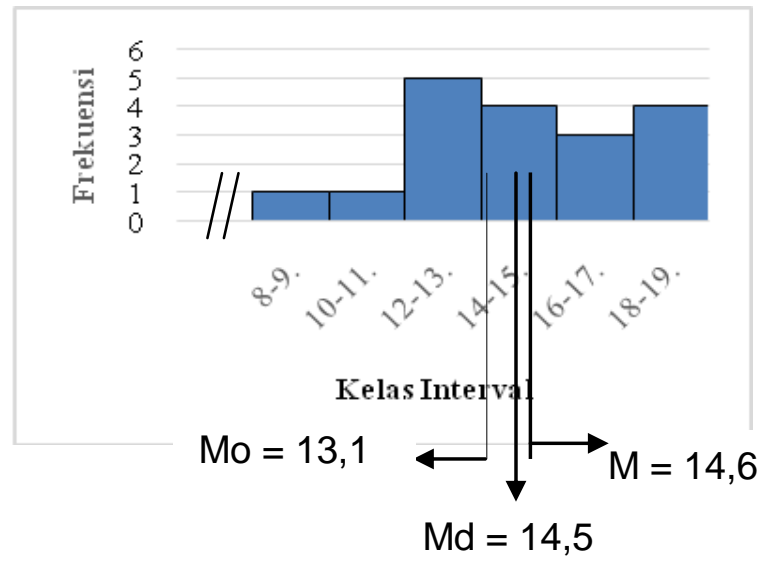

Gambar 2. Kurva Polygon Data Hasil Belajar IPS Kelompok Kontrol

Berdasarkan Gambar 2. terlihat bahwa sebaran data kelompok siswa yang dibelajarkan dengan menggunakan model pembelajaran konvensional menunjukkan $\mathrm{M}>\mathrm{Md}>\mathrm{Mo}(14,6>14,5>13,1)$. Hal ini menunjukkan bahwa sebagian besar skor cenderung rendah. Jika dikonversi ke dalam Penelitian Acuan Ideal Teoretik Skala Lima Berada pada kategori cukup.

Sebelum uji hipotesis dilakukan, terlebih dahulu dilakukan pengujian prasyarat terhadap sebaran data yang meliputi uji normalitas pada data kelompok eksperimen dan kelompok kontrol serta dilakukan uji homogenitas antar kelas terhadap sebaran data hasil belajar IPS.

Uji normalitas sebaran data dilakukan untuk membuktikan bahwa frekuensi data hasil penelitian benar-benar berdistribusi normal. Uji normalitas sebaran data dilakukan terhadap hasil belajar IPS kelompok eksperimen dan kelompok kontrol. Untuk mengetahui sebaran 
data penguasaan kompetensi pengetahuan IPS siswa berdistribusi normal atau tidak, maka data diuji menggunakan analisis Chi-Kuadrat $\left(\chi^{2}\right)$ pada taraf signifikasi $5 \%$ dan derajat kebebasan $\mathrm{db}=\mathrm{k}$-parameter $-1(\mathrm{db}=\mathrm{k}-2-1)$. Rekapitulasi hasil uji normalitas data kelompok eksperimen dan kelompok kontrol disajikan pada Tabel 3.

Tabel 3. Hasil Uji Normalitas Sebaran Data

\begin{tabular}{lccc}
\hline $\begin{array}{c}\text { Kelompok Data Hasil } \\
\text { Belajar }\end{array}$ & $\chi^{2}{ }_{\text {hitung }}$ & $\chi^{2}{ }_{\text {tabel }}$ & Keterangan \\
\hline Kelompok Eksperimen & 4,899 & 7,185 & Normal \\
Kelompok Kontrol & 2,992 & 7,815 & Normal \\
\hline
\end{tabular}

Berdasarkan perhitungan di atas hasil uji normalitas sebaran data hasil belajar IPS pada taraf signifikasi $5 \%$ dan derajat kebebasan $\mathrm{dk}=\mathrm{k}$-parameter-1(dk=k-2-1) menggunakan rumus Chi-Kuadrat $\left(\chi^{2}\right)$ diperoleh kelompok siswa yang dibelajarkan dengan menggunakan model pembelajaran Snowball Throwing Berbasis Penilaian Proyek $x^{2}$ nitung $=4,899$ dengan $\mathrm{db}=3$ dan taraf signifikasi $5 \%$ sehingga diperoleh harga $x^{2}$ tabel $=7,185$, ini berarti bahwa $x^{2}$ hitung $<x^{2}$ tabel maka hasil belajar IPS pada kelompok siswa yang dibelajarkan dengan menggunakan model pembelajaran Snowball Throwing Berbasis Penilaian Proyek berdistribusi normal. Sedangkan hasil belajar IPS kelompok siswa yang dibelajarkan dengan menggunakan model pembelajaran Konvensional $X^{2}$ hitung $=2,992$ pada taraf signifikasi $5 \%$ dan $\mathrm{db}=3$ diperoleh $\mathrm{x}^{2}$ tabel $=7,815$, ini berati $\mathrm{X}^{2}$ hitung $<\mathrm{X}^{2}$ tabel maka data hasil belajar IPS kelompok siswa yang dibelajarkan dengan menggunakan model pembelajaran Konvensional juga berdistribusi normal. Uji homogenitas dilakukan terhadap varians pasangan antar kelompok eksperimen dan kontrol. Uji homogenitas varians antar 2 kelompok menggunakan Uji-F pada taraf signifikansi 5\%. Kriteria data homogen jika $F_{\text {hitung }}<$ $F_{\text {tabel, }}$ sedangkan kriteria pengujian varians tidak homogen jika $F_{\text {hitung }}>F_{\text {tabel. }}$ Rangkuman hasil uji homogenitas varians antar kelompok eksperimen dan kontrol disajikan pada tabel 4.

Tabel 4. Rangkuman Hasil Uji Homogenitas Varians

\begin{tabular}{cccc}
\hline Sumber Data & $\mathbf{F}_{\text {hitung }}$ & $\begin{array}{c}\mathbf{F}_{\text {tabel }} \text { dengan Taraf } \\
\text { Signifikansi 5\% }\end{array}$ & Status \\
\hline $\begin{array}{c}\text { Post-test Kelompok eksperimen dan } \\
\text { kontrol }\end{array}$ & 1,05 & 2,23 & Homogen \\
\hline
\end{tabular}

Dari hasil perhitungan, diperoleh kelompok siswa yang dibelajarkan dengan menggunakan model pembelajaran Snowball Throwing Berbasis Penilaian Proyek maupun kelompok siswa yang dibelajarkan dengan menggunakan model pembelajaran Konvensional yaitu $\mathrm{F}_{\text {hitung }}=1,05$ dan $\mathrm{F}_{\text {tabel }}=2,23$ dengan $\mathrm{db}_{\text {pembilang }}=21, \mathrm{db}_{\text {penyebut }}=17$, dan taraf signifikansi $5 \%$. Hal ini berarti $F_{\text {hitung }}<\mathrm{F}_{\text {tabel }}$ sehingga varians data hasil belajar IPS dikategorikan homogen.

Uji hipotesis digunakan untuk menguji hipotesis yang telah dikemukakan. Hipotesis yang diuji dalam penelitian ini adalah terdapat pengaruh signifikan model pembelajaran Snowball Throwing berbasis penilaian proyek terhadap hasil belajar IPS siswa kelas IV SD di Gugus IV Kecamatan Banjar Kabupaten Buleleng Tahun Pelajaran 2017/2018. Berdasarkan uji prasyarat analisis data, diperoleh bahwa data hasil belajar IPS kelompok eksperimen dan kelompok kontrol berdistribusi normal dan memiliki varians yang homogen. Setelah diperoleh hasil dari uji prasyarat analisis data, dilanjutkan dengan pengujian hipotesis penelitian $\left(\mathrm{H}_{1}\right)$ dan hipotesis $\left(\mathrm{H}_{0}\right)$. Pada uji hipotesis digunkan uji-t polled varians pada taraf signifikansi $5 \%$ dengan derajat kebebasan $\left(n_{1}+n_{2}\right)-2$. Kriteria pengujian adalah $\mathrm{H}_{0}$ 
ditolak jika $t_{\text {hitung }} \geq t_{\text {tabel }}$, sebaliknya jika $t_{\text {hitung }} \leq t_{\text {tabel }}$ maka $\mathrm{H}_{0}$ diterima dan $\mathrm{H}_{1}$ ditolak. Dari hasil perhitungan uji-t menggunakan polled varians disajikan pada Tabel 5 .

Tabel 5. Ringkasan Hasil Uji Hipotesis Hasil Belajar IPS

\begin{tabular}{lcccccc}
\hline $\begin{array}{c}\text { Kelompok Data Hasil } \\
\text { Belajar }\end{array}$ & Varians & $\mathbf{N}$ & Db & $\mathbf{t}_{\text {hitung }}$ & $\mathbf{t}_{\text {tabel }}$ & Kesimpulan \\
\hline $\begin{array}{l}\text { Kelompok Eksperimen } \\
\text { Kelompok Kontrol }\end{array}$ & 9,786 & 22 & 38 & 8,179 & 2,021 & $\begin{array}{c}t_{\text {hitung }}>t_{\text {tabel }} H_{0} \\
\text { ditolak }\end{array}$ \\
\hline
\end{tabular}

Berdasarkan analisis data diperoleh $t_{\text {hitung }}$ sebesar 8,179 dibandingkan dengan $t_{\text {tabel }}$ diperoleh dari tabel nilai-nilai dalam distribusi $\mathrm{T}$ dengan $\mathrm{dk}=22+18-2=38$ dan taraf signifikansi $5 \%$. Berdasarkan tabel nilai-nilai dalam distribusi $T$ diperoleh harga $t_{\text {tabel }}$ sebesar 2,021 . Karena $t_{\text {hitung }}>t_{\text {tabel }}(8,179>2,021)$ maka $H_{0}$ ditolak dan $H_{1}$ diterima. Hal ini berarti terdapat pengaruh signifikan model pembelajaran Snowball Throwing berbasis penilaian proyek terhadap hasil belajar IPS siswa kelas IV SD di Gugus IV Kecamatan Banjar Kabupaten Buleleng Tahun Pelajaran 2017/2018.

Pengaruh model pembelajaran Snowball Throwing berbasis penilaian proyek dan pembelajaran konvensional terhadap hasil belajar IPS siswa kelas IV yang dilakukan pasa SD di Gugus IV Kecamatan Banjar Kabupaten Buleleng semester genap tahun pelajaran 2017/2018. Sampel penelitian adalah siswa kelas IV SD Negeri 1 Banjar sebagai kelas eksperimen dan siswa kelas IV SD Negeri 5 Banjar sebagai kelas kontrol.

Hasil analisis data hasil belajar IPS menunjukkan bahwa terdapat pengaruh model pembelajaran Snowball Throwing berbasis penilaian proyek terhadap hasil belajar IPS. artinya adanya perbedaan hasil belajar IPS antara kelompok eksperimen dengan kelompok kontrol yang ditandai dengan lebih tingginya mean kelompok eksperimen daripada kelompok kontrol. Hasil tersebut didasarkan pada rata-rata skor hail belajar siswa dan hasil uji-t. Rerata hasil post-test siswa yang dibelajarkan dengan model pembelajaran Snowball Throwing berbasis penilaian proyek adalah 22,5. Rerata hasil post-test siswa yang dibelajarkan dengan model pembelajaran konvensional adalah 14,6. Hal ini berarti, rata-rata skor hasil belajar IPS kelompok eksperimen lebih tinggi daripada rata-rata skor hasil belajar IPS kelompok kontrol. Selain dilihat dari nilai rata-rata tersebut, pengaruh model pembelajaran Snowball Throwing berbasis penilaian proyek dapat dilihat berdasarkan hasil analisis uji-t yang diketahui $t_{\text {hitung }}=8,179$ dan $t_{\text {tabel }}=2,021$ untuk $\mathrm{db}=38$ pada taraf signifikan $5 \%$. Berdasarkan hasil perhitungan tersebut diketahui $t_{\text {hitung }}>t_{\text {tabel }}$, hal ini berarti terdapat pengaruh yang signifikan model pembelajaran Snowball Throwing berbasis penilaian proyek terhadap hasil belajar IPS pada siswa kelas IV SD semester genap tahun pelajaran 2017/2018 di Gugus IV Kecamatan Banjar.

Pada penelitian ini ditemukan beberapa temuan yaitu, pertama sebelum diterapkan model pembelajaran Snowball Throwing berbasis penilaian proyek nilai siswa masih rendah. Kedua, setelah menerapkan model pembelajaran Snowball Throwing berbasis penilaian proyek nilai rata-rata siswa berada dalam kategori baik. Perbedaan yang signifikan hasil belajar IPS antara kelompok siswa yang dibelajarkan dengan model pembelajaran Snowball Throwing berbasis penilaian proyek dan kelompok siswa yang dibelajarkan dengan menggunakan model pembelajaran konvensional disebabkan oleh beberapa faktor yaitu adanya perlakuan perbedaan langkah-langkah pembelajaran dan proses pembelajaran.

Hasil belajar yang diperoleh siswa dalam suatu periode tertentu ditentukan oleh faktor keaktifan siswa yang mengikuti proses pembelajaran. Selain itu, model pembelajaran yang digunakan oleh guru juga sangat berpengaruh terhadap hasil belajar siswa. Pada penerapannya, model pembelajaran Snowball Throwing berbasis penilaian proyek, proses pembelajarannya ini berpusat pada siswa, siswa lebih banyak beraktivitas dalam kegiatan pembelajaran, sehingga di dalam proses pembelajaran siswa lebih mendominasi dan cenderung bersifat aktif. Hal ini sesuai dengan penjelasan Kurniasih dan Berlin (2016:77) 
model pembelajaran Snowball Throwing 'bola salju bergulir' merupakan 'model pembelajaran yang menggunakan bola pertanyaan dari kertas yang digulung bulat berbentuk bola kemudian dilemparkan secara bergiliran di antara sesama anggota kelompok". Pendapat serupa juga disampaikan oleh Shoimin (2014:174) yang menyatakan bahwa, "model pembelajaran Snowball Throwing merupakan pengembangan dari model diskusi dan merupakan dari model pembelajaran diskusi dan merupakan bagian dari model pembelajaran kooperatif". Untuk menilai hasil belajar siswa, guru dapat menerapkan penilaian proyek pada model pembelajaran Snowball Throwing dengan memberikan sebuah tugas yang dikerjakan sesuai dengan waktu yang ditentukan oleh guru dengan tujuan agar guru dapat menilai kemampuan siswa secara langsung. Hal ini sesuai dengan penjelasan Sudaryono(2012:88) penilaian proyek merupakan "kegiatan penilaian terhadap suatu tugas harus diselesaikan dalam periode/waktu tertentu". Dengan demikian, model pembelajaran Snowball Throwing berbasis penilaian proyek pada dasarnya adalah melatih siswa untuk lebih tanggap menerima pesan dari orang lain atau kelompok lain, memikirkan jawabannya sendiri, aktif dalam mengerjakan tugas, dan menimbulkan kerjasama yang baik dengan kelompok. Penggunaan model pembelajaran Snowball Throwing dalam pembelajaran IPS mempermudah siswa dalam menyelesaikan soal-soal yang diberikan oleh guru dan dapat mempejelas pemahaman siswa terhadap materi pelajaran IPS.

Berdasarkan perlakuan yang diberikan pada proses pembelajaran, siswa kelompok eksperimen yaitu mampu melatih kepemimpinan siswa dan tanggung jawab siswa karena dalam proses pembelajaran ketua kelompok atau pemimpin kelompok menjelaskan materi yang sudah dijelaskan kepada anggota kelompoknya. Dengan adanya komunikasi yang baik dalam kelompok maka siswa dapat bertukar pikiran antara satu dengan yang lainnya, saling menghargai pendapat, berbagi pengetahuan dan menyampaikan pendapat, sehingga siswa dapat mengembangkan kemampuan berpikir dengan mampu membuat pertanyaan sendiri dan mengerjakan tugas kelompok yang diberikan oleh guru. Selain itu, siswa juga mampu menjawab pertanyaan yang didapatkan. Dengan siswa mampu menjawab pertanyaan dan mengerjakan tugas kelompok dengan baik, maka dapat mempengaruhi hasil belajar siswa sehingga hasil belajar IPS siswa meningkat.

Berdasarkan pemaparan di atas, maka dapat disimpulkan terdapat pengaruh yang signifikan model pembelajaran Snowball Throwing berbasis penilaian proyek terhadap hasil belajar IPS siswa kelas IV SD di Gugus IV Kecamatan Banjar Kabupaten Buleleng Tahun Pelajaran 2017/2018.

\section{Simpulan dan Saran}

Berdasarkan hasil penelitian dan pembahasan di atas, maka dapat disimpulkan yaitu terdapat pengaruh yang signifikan model pembelajaran Snowball Throwing berbasis penilaian proyek terhadap hasil belajar IPS pada siswa kelas IV SD semester genap tahun pelajaran 2017/2018 di Gugus IV Kecamatan Banjar. Hal ini dapat dilihat berdasarkan pengujian hipotesis dengan menggunakan uji-t yang diperoleh $t_{\text {hitung }}$ sebesar 8,179 dan $t_{\text {tabel }}$ sebesar 2,021 . Karena $t_{\text {hitung }}>t_{\text {tabel }}(8,179>2,021)$ maka $H_{0}$ ditolak dan $H_{1}$ diterima. Selain itu dilihat dari nilai rerata hitung, kelompok eksperimen memiliki nilai rata-rata lebih tnggi daripada kelompok kontrol $(22,5>14,6)$. Sehingga dapat disimpulkan bahwa model pembelajaran Snowball Throwing berbasis penialaian proyek memiliki pengaruh yang signifikan terhadap hasil belajar PKn siswa kelas IV SD di Gugus IV Kecamatan Banjar Kabupaten Buleleng Tahun Pelajaran 2017/2018.

Berdasarkan hasil penelitian, maka dapat disarankan beberapa hal berikut: 1) Disarankan kepada siswa-siswa di Sekolah Dasar agar lebih aktif dalam mengikuti pembelajaran dan terus mengembangkan pemahamannya dengan membangun sendiri pengetahuan tersebut melalui pengalaman sehingga dapat meningkatkan hasil belajar. 2) Disarankan kepada guru-guru di sekolah dasar agar lebih berinovasi dalam pembelajaran dengan menerapkan model maupun strategi pembelajaran yang inovatif dalam pembelajaran dan menekankan keaktifan siswa sehingga dapat meningkatkan hasil belajar siswa.3) 
Disarankan kepada Kepala Sekolah agar memberikan dorongan kepada guru-guru untuk menerapkan model-model pembelajaran yang inovatif untuk meningkatkan kualitas pembelajaran di Sekolah, salah satunya dengan cara mensosialisaikan penerapan suatu model pembelajaran yang inovatif, sehingga hasil belajar siswa meningkat. 4) Bagi peneliti lain, hasil belajar IPS siswa dapat diteliti dalam penelitian ini hanya terbatas pada hasil belajar pada ranah kognitif. Hendaknya untuk memperoleh hasil belajar siswa yang lebih komperhensif dalam pembelajaran maka perlu diadakan penelitian sejenis yang tidak hanya menyelidiki hasil belajar pada ranah kognitif tetapi juga mencankup ranah afektif dan psikomotor siswa.

\section{Daftar Rujukan}

Agung, A. A. G. 2014. Metodologi Penelitian Pendidikan (Cet. Ke-2). Malang: Aditya Media Publishing.

Dewi, M. P. 2013. Pengaruh Model Pembelajaran Snowball Throwing Terhadap Hasil Belajar IPA Siswa Kelas V SD di Gugus Sri Kandi Kecamatan Denpasar Timur. Mimbar PGSD. Retrieved from https://ejournal.undiksha.ac.id/index.php/JJPGSD/article/viewFile/924/794.

Djahir, Ahmad Rifaldi, Daud K. Walanda, dan Baharuddin Hamzah. 2014. Penerapan Model Pembelajaran Snowball Throwing Berbantuan Kode Smiles pada Materi Hidrokarbon terhadap Hasil Belajar Siswa Kelas XI SMA Negeri 5 Palu. J. Akademika Kim. Vol. 3 No. 4 Hal. 222-229. Tersedia Pada http://jurnal.untad.ac.id/jurnal/index.php/JAK/article/view/7838.

Hidayati, D. 2010. Pengembangan Pendidikan IPS SD 3 SKS. Direktorat Jenderal Pendidikan Tinggi: Kementerian Pendidikan Nasional.

Majid, A. 2011. Perencanaan Pembelajaran. Bandung: PT REMAJA ROSDAKARYA.

Rasana, P. R. 2009. Laporan Sabbatical Leave Model-model Pembelajaran. Singaraja: Universitas Pendidikan Ganesha.

Rosidah, Ani. 2017. Penerapan Model Pembelajaran Kooperatif Snowball Throwing untuk Meningkatkan Hasil Belajar Siswa pada Pembelajaran IPS. Jurnal Cakrawala Pendas Vol. $\quad 3 \quad$ No.2 $\quad$ Hal.29-36. $\quad$ Tersedia $\quad$ Pada https://jurnal.unma.ac.id/index.php/CP/article/view/593.

Sunistini D, Luh, Ni Wyn. Arini, I Gd. Margunayasa. 2013. Penerapan Model Snowball Throwing Berbantuan Media Sederhana Untuk Meningkatkanhasil Belajar Matematika Siswa di SD NO 1 Petandakan. Mimbar PGSD Undiksha Vol.1 No. 1 Hal. 1-10. Tersedia Pada https://ejournal.undiksha.ac.id/index.php/JJPGSD/article/view/870/742.

Shoimin, A. 2014. 68 Model Pembelajaran Inovatif dalam Kurikulum 2013. Yogyakarta: ArRuzz Media.

Sugiyono. 2016. Metode Penelitian Pendidikan. Bandung: Alfabeta.

Suwatra, I. W. dkk. 2015. Belajar dan Pembelajaran. Singaraja: Universitas Pendidikan Ganesha. 
Yuliati. 2015. Efektifitas Penggunaan Model Kooperatif Tipe Snowball Throwing untuk Meningkatkan Hasil Belajar Siswa pada Materi Sistem Pertidaksamaan Linear di Kelas XI-IS-2 SMA Negeri 7 Banda Aceh. Jurnal Peluang, Volume 3, Nomor 2, Hal. 65-78. Tersedia Pada : http://www.jurnal.unsyiah.ac.id/peluang/article/view/5718. 